\title{
IMPLEMENTASI MANAJEMEN PENGEMBANGAN MUTU DOSEN PERGURUAN TINGGI AGAMA ISLAM NEGERI DI PROVINSI ACEH
}

\author{
${ }^{1}$ Husaini, ${ }^{2}$ Jumat Barus \\ ${ }^{1,2}$ Institut Agama Islam Negeri Lhokseumawe \\ ${ }^{1}$ husaini@iainlhoksemawe.ac.id, \\ 2jumatbarus@iainlhoksemawe.ac.id
}

\begin{abstract}
This study aims to analyze the implementation and evaluation of quality development of PTAIN lecturers in Aceh. A qualitative research method and descriptive approach is applied in the research. The research result shows that the implementation of quality development of PTAIN lecturers in Aceh is done by referring to the strategic plan or programs prepared at the beginning of the year. The forms of implementation of lecturer quality development include room visits, inspection to lecturers' learning devices, and providing opportunities for lecturers to increase their competence and professionalism through various exercises and benchmarking to other leading Islamic universities. The evaluation for the lecturers quality development is carried out through routine meetings, weekly, mid semester, and annually at the beginning of academic year. The results of the evaluation will become supplementary materials for the institutions in following up the lecturers' performance on the lecturers' daily activities. The development carried out to the lecturers are in the form of admonition, providing training and development to increase the lecturers' competence and professionalism, and also doing routine religious lectures.
\end{abstract}

Keywords: Implementation, Lecturer Quality, Evaluation.

\section{ABSTRAK}

Tujuan penelitian ini untuk mengetahui bagaimana implementasi dan evaluasi pengembangan mutu dosen PTAIN di Provinsi Aceh. Metode yang digunakan adalah kualitatif dengan pendekatan diskriptif. Sumber informan adalah rektor dan dosen. Hasil penelitian menunjukkan pelaksanaan peningkatan mutu dosen mengacu pada renstra tahunan lembaga. Pelaksanaan peningkatan mutu dosen mengacu pada standar kompetensi yang meliputi kunjungan ruangan, pemeriksaan perangkat pembelajaran. dan pemberian kesempatan Dosen-Dosen meningkatkan kompetensi dan profesionalitasnya melalui berbagai latihan dan studi banding ke Institusi lembaga pendidikan tinggi agama Islam lain. Evaluasi peningkatan mutu dosen dalam meningkatkan mutu di Perguruan Tinggi Agama Islam Negeri di Aceh dilakukan melalui rapat rutin mingguan, rapat tengah semester dan rapat awal tahun pelajaran. Hasil evaluasi menjadi bahan tambahan dalam menindaklanjuti kinerja dosen terhadap prilaku sehari hari dan pembinaan lebih lanjut kepada para Dosen. Adapun bentuk-bentuk pembinaan yang dilakukan terhadap para Dosen meliputi upaya pemanggilan dan pemberian peringatan, pemberian pelatihan bagi peningkatan kompetensi dan profesionalitas Dosen, musyawarah melalui rapat kerja, pengajian, dan studi banding ke PTAIN unggulan.

Kata Kunci: Pelaksanaan, dan Evaluasi Mutu Dosen

\section{A. PENDAHULUAN}

Pendidikan menjadi komponen fundamental dalam proses pembangunan nasional jangka panjang dalam pertumbuhan dan kemajuan ekonomi suatu negara (Acs, Szerb, \& Autio, 2015).
Pendidikan sebagai investasi masa yang akan datang dalam pembangunan sumber daya manusia, dimana peningkatan keterampilan dan skill diyakini sebagai faktor pendukung yang utama dalam mengarungi kehidupan manusia yang penuh 
dengan ketidakpastian dan keraguan dalam menjali kehidupan yang penuh problematika (Bashori, Prasetyo, \& Susanto, 2020). Dalam rangka inilah pendidikan diperlukan dan dipandang sebagai kebutuhan dasar bagi masyarakat yang ingin maju. Demikian halnya bagi masyarakat Indonesia yang memiliki wilayah yang sangat luas (Fadjar, 2001).

Pendidikan Islam adalah hal yang terpenting dalam menjalani kehidupan dan peradaban Islam. Kehadiran pendidikan Islam membawa rahmat dan nikmat bagi sekalian alam generasi muda dengan tidak memiliki bekal pendidikan agama yang memadai akan sangat membahayakan bagi perkembangan Islam di masa mendatang, yang menyebabkan munculnya berbagai kehawatiran dalam hidup masyarakat muslim pada umumnya dan masyarakat dunia (Zarkasyi, 2012). Kehidupan generasi muda dengan tidak mendapatkan bekal pendidikan Islam yang memadai, akan menyebabkan kehancuran dan keterbelakangan bagi mereka sendiri, bahkan dapat memicu persoalan-persoalan dalam masyarakat secara umum (Dhaniarti, et, al., 2016).

Pendidikan menjadi bagian integral peradaban sebuah bangsa. Melihat urgensitas tersebut perlu sebuah kebijakan konkrit, salah satunya revitalisasi manajemen perguruan tinggi dengan menekankan pada aspek peningkatan mutu berkelanjutan (Yorke, 2000). Isu strategis terkait mutu berkelanjutan adalah peningkatan kompetensi dan profesionalisme dosen sebagai instrument pokok keberhasilan pendidikan di Perguruan Tinggi. Dalam kacamata undangundang peningkatan kualitas sumber daya manusia (SDM) seutuhnya melalui rencana pendidikan yang dilakukan secara sistematis dan terarah berdasarkan kepentingan nasional yang mengacu pada kemajuan ilmu pengetahuan dan teknologi dilandasi oleh keimanan dan ketaqwaan kepada Tuhan yang Maha Esa.

Efektivitas adalah ketercapaian hasil atau tujuan. Penyelenggaraan dikatakan efektif apabila proses pendidikan yang dilaksanakan berkualitas. Ketersediaan layanan akademik yang bermutu serta kehadiran dosen yang kompeten mutlak diperlukan dalam penciptaan mutu berkelanjutan (Safitri, et, al., (2019).

Keberhasilan pendidikan merupakan suatu hal yang dicita-citakan oleh para penyelenggara dan pelaksana pendidikan. Selain dari penyelenggara dan pelaksana pendidikan itu sendiri, keberhasilan pendidikan juga merupakan harapan dari setiap orang, baik secara individu maupun secara kelompok dalam masyarakat, dari 
generasi ke generasi berikutnya (Mukhtar, 2020).

Misi pendidikan Islam lebih menyeluruh dan luas daripada pendidikan umum. Paling tidak ada dua misi yang harus dipikul atau diemban oleh lembaga pendidikan Islam, khususnya lembaga perguruan tinggi agama Islam (sekolah tinggi agama Islam, institute, maupun universitas Islam), yaitu misi akademik dan misi keagamaan. Dua misi tersebut terkadang memimiliki karakter yang berhadapan bahkan berbenturan sehingga tidak mudah bagi perguruan tinggi agama Islam untuk menentukan salah satu misi guna menghindari kasus tabrakan. Keduanya sangat penting karena menjadi alasan historis berdirinya perguruan tinggi (Arwildayanto, 2012).

Kehadiran perguruan tinggi agama Islam di tengah masyarakat perwujudan dan harapan cita-cita orang Islam yang telah lama didambakan sejak zaman penjajahan belanda dan jepang dari hati sanubari umat Islam Indonesia. Akan tetapi setelah Indonesia merdeka diperlukan adanya Sekolah Tinggi Agama Islam (Wajdi, 2016). Apalagi dengan kedatangan kaum Kristen yang banyak mendirikan sekolah Kristen dengan biaya rendah dan mutu pengelola yang berkualitas dan di dikelola oleh orangorang yang berpendidikan tinggi maka keperluan untuk mendirikan sekolah tinggi agama Islam itu semakin berkembang pesat sehingga pengaruh Islam akan semakin maju dan berkembang dan kalau tidak pengaruh Islam akan semakin kecil (Zein, 2018), (Nasr \& Leaman, 2013).

Keberadaan Perguruan tinggi agama Islam Negeri (PTAIN) Perguruan tinggi agama Islam swasta (PTAIS) dapat memenuhi dua harapan. Pertama, harapan yang terkait dengan eksistensinya sebagai lembaga keilmuan dituntut untuk memenuhi tugas sebagai pendidikan dan pengajaram, penelitian, pengembangan ilmu pengetahuan agama Islam, serta pengabdian masyarakat. Kedua, adalah harapan yang terkait erat dengan kelembagaan PTAIN dan PTAIS sebagai lembaga pendidikan keagamaan Islam (Abdullah, 2017).

Berkenaan dengan sumber daya manusia di PTAIN setidaknya ada dua hal yang dapat dilakukan. Pertama, salah satu tolok ukur utama dalam penerimaan calon tenaga pendidik adalah kemampuan akademik yang didasarkan pada jenjang pendidikan tertentu (Master dan Doktor) sebagaimana yang telah di tentukan oleh Departemen Agama RI. Selain itu, perlu pula memperhatikan potensi akademis calon tenaga pendidik melalui karya ilmiah yang dihasilkan, baik berupa buku, jurnal, artikel dalam surat kabar, dan hasil-hasil penelitian, 
kedua, mengingat keterbatasan formasi pengangkatan tenaga edukatif PNS, perlu diupayakan pengangkatan tenaga pendidik honorer melalui system kontrak dengan imbalan yang wajar dan manusiawi

Berbicara mengenai kualitas sumber daya manusia dalam pendidikan Islam, maka pemerintah bersama masyarakat akan terus berupaya mewujudkan cita-cita dan amanat undang undang Dasar 1945 melalui berbagai alternative usaha pembangunan pendidikan yang lebih luas, berkualitas antara lain melalui pengembangan sumber daya manusia dan perbaikan sistem mutu pendidikan melaui program beasiswa tingkat nasional dan internasional, perbaikan sarana dan prasarana. namun pada realitasnya upaya pemerintah belum cukup berarti dalam meningkatkan kuailtas sumber daya manusia. Salah satu indikator kekurang berhasilan ini ditunjukkan antara lain dengan muncul dedikasi moral di masyarakat kenakalan remaja semakin merajalela.

Sebagai lembaga pendidikan Islam sebagai the transmition of Islamic teaching (penyebaran ajaran Islam), the maintenance of Islamic tradition (mempertahankan tradisi Islam), dan the reproduction of ulama (pencetak ulama) akan jauh lebih optimal jika ditunjang dengan struktur kelembagaan yang lebih besar dan kuat dalam format kualitas sumber daya manusai sehingga menghasilkan kelembagaan Perguruan Tinggi Keagamaan Islam Negeri (PTAIN), di Aceh lebih maju dan berkembangan sesuai dengan harapan masyarakat.

Dalam mencermati kebutuhan para stake holder dan perkembangan PTAIN sebagaimana dipaparkan di atas, maka perlu dilakukan analisis pengembangan mutu dosen secara serius dan mendalam, sehingga PTAIN dimaksud mengetahui program pengembangan dosen yang semestinya dilakukan, sehingga tujuan PTAIN di aceh dilakukannya perkembangan tersebut mencapai sasaran sebagaimana yang didambakan oleh masyarakat, Yang mampu meningkatkan mutu lulusannya sebagaimana yang diharapkan oleh stake holder yang ada. Saat ini, Perguruan Tinggi Agama Islam Negeri di provinsi Aceh telah semakin berkembang, dan kontribusi yang diberikan juga semakin meningkat dari waktu ke waktu. Namun demikian, tantangan yang bakal dihadapi ke depan semakin berat dan kompetitif, seiring dengan perkembangan zaman dan teknologi yang semakin canggih. Disamping itu masih banyak hal yang mengkhawatirkan para lulusan khususnya terkait dengan semakin sulitnya bersaing dalam merebut kesempatan kerja di era globalisasi ini. 


\section{B. TINJAUAN PUSTAKA}

Implementasi yang penulis maksud adalah sebuah hasil pekerjaan yang baik dalam melakukan sebuah pekerja yang aka diterapkan dalam sebauh institusi. dalam Kamus Besar Bahasa Indonesia diartikan sebagai pelaksanaan atau penerapan. Artinya yang dilaksanakan adalah Kebijakan yang telah dirancang/didesain untuk dijalankan.

Manajemen adalah keterampilan untuk memperoleh sesuatu hasil dalam pencapaian tujuan melalui kegiatan. Seperti mengatur mengelola, merancang inilah penerjemahan manajemen secara umum. (Martin, 2016). Manajemen adalah seperangkat kemampuan organisasi khusus untuk memberikan hasil kepada pelanggan dalam bentuk layanan baik secara sarana dan prasarana yang memadai yang sesuai dengan keinginanya dalam meningkatkan mutu lembaga juga harus di perhatikan secara manajemen yang teratur

Pengembangan adalah penyusunan suatu yang baru untuk menyempurnakan yang ada secara keseluruhan atau memperbaiki yang telah ada. Pengembangan sistem merupakan langkah mengubah, menggantikan, atau merencanakan kembali sistem lama menjadi sistem yang baru baik secara kecilan maupun keseluruhan untuk memperbaiki sistem yang telah ada.

Dalam sebuah lembaga yang dinamis pengembangan merupakan suatu tindakan yang penting untuk dilakukan, tujuannya adalah agar mekanisme atau sistem kerja pada lembaga tersebut menjadi lebih baik, semua aspek lebih terintegrasi pada suatu sistem/peraturan. Tolak ukur suatu pengembangan bagaimana yang lama dan yang baru terintegrasi sehingga menghasilkan titik temu dalam pengambilan keputusan pada tingkat pimpinan suatu.

Mutu adalah indicator baik dan buruk suatu benda, nilai tinggi atau derajat seseorang berupa kepandaian, kecerdasan, kecakapan, dan sebagainya. Mutu juga dapat didefinisikan sebagai cara mengidentifikasi tujuan-tujuan jangka panjang yang membantu menetapkan tujuan jangka menengah dan jangka pendek yang mengarah pada tujuan (Amtu, 2011). Menurut Sallis, mutu didefinisikan sebagai ciri khas sutau benda yang menyeluruh barang atau jasa yang dalam memenuhi kebutuhan yang diharapkan. Dalam konteks pendidikan mutu mencakup input, proses dan output sumber daya manusia (Sallis, 2012).

Pengembangan mutu dosen adalah suatu metode yang bertumpu pada dosen sendiri dan lembaga setempat, dalam 
mengaplikasikan sekumpulan teknik, komponen kapasitas dan kemampuan organisasi guna memenuhi kebutuhan masyarakat (Rosita \& Musnaini, 2020). Sedangkan yang dimaksud dengan Pengelolaan Mutu pendidikan tinggi adalah cara mengelola perguruang tinngi sesuai dengan standar mutu internal dilaksanakan oleh jajaran dan semua unsur sejak dini secara sistematis dan berkesimambungan sesuai kebutuhan para pelanggan, baik masa sekarang maupun yang akan datang.

\section{METODE PENELITIAN}

Penelitian ini dilakukan di tiga lokasi PTAIN di Aceh yaitu UIN Ar-Raniry Banda Aceh, IAIN Langsa dan STAIN Gajah Putih Takengon. Penelitian ini, menggunakan metode deskriptif analitik yaitu suatu metode yang mengambarkan keadaan yang sedang berlangsung pada saat penelitian dilakukan berdasarkan fakta yang ada, dengan pendekatan kualitatif. Pendekatan kualitatif dilakukan pada situasi lapangan penelitian yang bersifat alamiah, sebagaimana adanya tanpa dimanipulasi terutama terhadap data yang dikumpulkan. Menurut Moleong, (2011), metode yang sering digunakan dalam penelitian kualitatif yaitu pengamatan, wawancara, catatan lapangan dan pengunaan dokumen.
Dengan pendekatan kualitatif diharapkan deskripsi atas gejala yang tampak di lapangan dapat diinterpretasikan isi dan maknanya. Studi ini sangat deskriptif, yakni mengumpulkan data sebanyak-banyaknya dan dituangkan dalam bentuk laporan dan uraian. Alasan metode dan pendekatan tersebut dipilih karena masalah yang dikaji menyangkut masalah yang sedang terjadi dan berkembang dalam pengembangan mutu dosen. Teknik pengumpulan data dengan menggunakan metode observasi, wawancara, dokumentasi teknik menyalin dokumen, untuk mengumpulkan informasi yang benar dan tepat, sehingga kebenaran data yang diperoleh dapat dipertanggungjawabkan.

Sumber data yang digunakan adalah data Primer berupa kata-kata dan tindakan orang yang diamati atau diwawancarai yang dicatat melalui catatan tertulis atau rekaman. Dalam penelitian ini, menggunkan teknik sampling dengan cara mewawancarai pihak pihak yang dapat memberikan keterangan yang benar tentang implementasi Manajemen pengembangan mutu dosen Perguruan tinggi agama Islam negeri di Aceh yaitu UIN Ar-Raniry Banda Aceh, IAIN Langsa dan STAIN Gajah Putih Takengon. Sedangkan Data Sekunder adalah data tambahan yang berupa dokumen, arsip, buku, dan sebagainya, yang 
berkaitan dengan Studi Peningkatan Mutu mutu dosen Perguruan tinggi agama Islam negeri di Aceh. . Analisis data dalam penelitian ini adalah menggunakan metode kualitatif, dimana proses mencari dan menyusun data secara sistematis diperoleh dari hasil wawancara, catatan lapangan, dokumentasi dan teknik menyalin, dengan cara mengorganisasikan data ke dalam kategori, menjabarkan ke dalam unit-unit, melakukan sintesa, dan membuat kesimpulan sehingga mudah dipahami peneliti dan orang lain (Sugiono, 2017).

Data yang dianalisis dalam penelitian ini adalah hasil kajian secra mendalam dari sumber penelitian berdasarkan hasil wawancara dengan Ketua LPM di UIN ArRaniry Banda Aceh, IAIN Langsa dan STAIN Gajah Putih Takengon serta dosen, sekaligus sebagai Sebagai peserta mendapat program studi lanjutan, serta hasil observasi terhadap kinerja program lanjutan yang sedang berlangsung. Selain itu data dokumentasi tentang profil UIN ArRaniry Banda Aceh, IAIN Langsa dan STAIN Gajah Putih Takengon, dokumen administrasi dan akademik terkait dengan program Peningkatan Mutu mutu dosen di UIN Arraniry Banda Aceh, IAIN Langsa dan STAIN Gajah Putih Takengon.

\section{HASIL DAN PEMBAHASAN}

Secara umum terdapat empat hasil penelitian atau temuan dalam penelitian ini. Adapun uraian hasil temuan tersebut dapat dikemukakan sebagai berikut:

\section{Pelaksanaan Pengembangan Mutu Dosen di UIN Ar Raniry}

Pelaksanaan dalam konteks penelitian ini adalah tahap implementasi dari rencana yang telah disusun dalam rencana pengembangan mutu dosen yang terdapat pada renstra maupun dalam beberapa rapat awal dan akhir tahun. Peningkatan mutu yang diharapkan oleh PTAIN tidak akan tercapai apabila rencana yang telah disusun tidak dilaksanakan. Oleh karena itu, rencana yang telah buat secara baik pada tahap perencanaan harus dilaksanakan dan didukung oleh semua pihak terkait sehingga dapat mencapai tujuan sebagaimana yang diharapkan. Dengan demikian, perencanaan tersebut menjadi pedoman yang harus dipatuhi khususnya oleh para pimpinan sebagai pelaksana yang memiliki power dalam mengeksekusi semua program dimaksud

Dalam usahanya untuk mengembangkan mutu sumber daya manusia, khususnya dosen, PTAIN ini telah melakukan kerjasama dengan provider scholarship (penyedia beasiswa) seperti LPSDA Banda Aceh, Mora Scholarship di Kementerian Agama, dan LPDP 
Kementerian Keuangan, sebagaimana dijelaskan dalam kutipan wawancara berikut ini:

Untuk meningkatkan mutu dosen khususnya dalam hal peningkatan jenjang pendidikan dosen, UIN kami melakukan kerjasama dengan beberapa provider scholarship seperti LPSDA, Mora Scholarship di bawah Kementerian Agama, dan LPDP dari Kementerian Keuangan. Dalam hal ini, kami mengundang pihak-pihak tersebut untuk memberikan materi bagi dosen-dosen kami yang masih berstatus S2, tentang trik-trik yang bisa dilakukan untuk mempermudah para dosen agar berhasil mendapatkan beasiswa-beasiswa dimaksud. Saat ini, dosen yang bergelar Doktor masih sedikit, yaitu $30 \%$, dan Wakil Rektor I memiliki target minimal 60 orang harus submit untuk mengikuti program doktor (MZ, 2019)

Berdasarkan kutipan wawancara dimaksud, diketahui bahwa UIN Ar Raniry memperlihatkan keseriusan mereka untuk meningkatkan profesionalitas dalam hal peningkatan jenjang pendidikan para dosen, yaitu dengan mencari dan menjalin kerjasama dengan para penyedia beasiswa, melatih dosen tersebut, dan mengirimkan mereka untuk mengikuti studi lanjut baik di dalam maupun luar negeri sesuai dengan kebutuhan. Pimpinan universitas ini melakukan komitmen perencanaannya dengan melakukan aksi nyata dengan berusaha mengirimkan para dosen bergelar Magister untuk melanjutkan perkuliahannya ke jenjang S3 di institusi yang mereka inginkan. Bahkan Wakil Rektor bidang Akademik berkomitmen dan membuat program untuk mengirimkan minimal 60 orang dosen untuk mengikuti studi lanjut Doktor pada tahun 2019.

Pengembangan mutu dosen di PTAIN tidak hanya sampai pada tahap usaha untuk pengiriman dosen untuk mengikuti studi lanjut sebagaimana telah dipaparkan di atas, institusi ini juga melakukan program akselerasi Profesor/Guru Besar. Salah satu PTAIN di Aceh telah menargetkan untuk mempercepat proses kenaikan jabatan fungsional bagi 5 (lima) orang dosen dari Lektor Kepala ke Guru Besar. Dalam hal tersebut, PTAIN ini memberi pendampingan bagi ke 5 orang dosen dimaksud, agar mereka tidak mengalami kesulitan dan tetap fokus dalam pemenuhan berbagai syarat untuk mencapai gelar akademik tertinggi, Profesor. Hal ini sesuai dengan penjelasan yang disampaikan, sebagai berikut:

Kami juga memiliki program lain untuk meningkatkan mutu dosen, 
yaitu program percepatan atau akselerasi Profesor. Di tahun ini (2019), kami mempunyai target minimal 5 (lima) orang dosen harus submit Guru Besar. Hingga saat ini sudah 4 (empat) orang dosen yang submit, tinggal 1 (satu) orang dosen lagi yang belum selesai, dan mudahmudahan di akhir Nopember ini beliau bisa menyelesaikan dan melengkapi semua persyaratan yang dibutuhkan. Dalam program percepatan ini, Lembaga Penjaminan Mutu bertugas untuk memberi pendampingan atau membantu halhal yang dibutuhkan sehingga para dosen tetap fokus dan mampu menyelesaikannya tepat waktu (BM, 2019).

Program tersebut menjadi prioritas bagi UIN di Aceh, karena keberadaan Profesor sangat dibutuhkan dalam meningkatkan mutu mahasiswa dan lulusan. Eksistensi para Guru Besar tersebut menjadi salah satu indikator berkualitas atau tidaknya sebuah perguruan tinggi, yang tentu saja akan sangat berpengaruh bagi peningkatan nilai Akreditasi Program Studi maupun Akreditasi Perguruan Tingginya.

Perihal peningkatan kompetensi dan profesionalitas Dosen di UIN Ar Raniry, institusi ini sering mengutus beberapa Dosen bidang ilmu mengikuti berbagai kegiatan pendidikan dan pelatihan yang diadakan oleh pusat dan balai pelatihan keagamaan Banda Aceh. Namun, tidak jarang pihak institusi juga mengundang beberapa narasumber untuk memberikan pelatihan kepada para Dosen, yang sering diistilahkan sebagai in-house training, misalnya micro teaching bagi semua dosen khususnya dosen-dosen baru, kegiatan duta mutu, dan refreshment auditor sebagaimana kutipan wawancara berikut:

Untuk peningkatan kapasitas para dosen, kita melakukan beberapa cara, yaitu mengadakan kegiatan pelatihan micro teaching bagi semua dosen, khususnya dosen baru. Disamping itu, kita juga memiliki program duta mutu, yakni mengirim dosen terbaik untuk belajar menyusun dokumen SPMI, kemarin kita bawa ke Bali, syaratnya mereka (dosen itu) harus menjadi auditor kita. Auditor kita saat ini berjumlah 60 orang. Kemudian kita merekrut auditor baru, melakukan refreshment auditor lama yang semuanya adalah dosen, dan auditor terbaik kita bawa ke luar daerah, dan tahun ini rencananya ke Bali (MZ, 2019) 
Penjelasan pada kutipan wawancara di atas menunjukkan bahwa PTAIN melakukan beberapa usaha untuk mengembangkan mutu dosen, tidak hanya untuk meningkatkan kapasitasnya sebagai dosen, namun juga meningkatkan kemampuan dosen untuk menjadi auditor mutu internal, dan memberikan reward bagi mereka yang berprestasi, yakni melakukan perjalanan dinas sekaligus refreshing ke luar daerah. Hal ini tentunya memberikan motivasi dan semangat yang tinggi bagi para dosen untuk selalu berusaha meningkatkan kemampuan diri secara berkelanjutan. Secara otomatis, hal tersebut akan memberikan sumbangan yang berharga bagi institusinya.

Dari informasi yang diperoleh, UIN Ar Raniry diketahui telah melaksanakan beberapa perencanaan pengembangan mutu dosen yang telah dimasukkan pada renstra maupun yang telah direncanakan dan dibahas pada beberapa rapat awal dan akhir tahun. Para pimpinan institusi, fakultas, maupun unit kerja lainnya mendukung rencana-rencana tersebut, dan hampir semua yang direncanakan pada renstra terimplementasi secara baik. Dengan demikian dapat disimpulkan bahwa renstra dan hasil rapat di awal dan akhir tahun menjadi acuan atau pedoman dalam menjalankan roda institusi.
Pelaksanaan Pengembangan Mutu Dosen di IAIN Langsa

Pelaksanaan pengembangan mutu di IAIN Langsa pada umumnya masih sangat terbatas pada tataran pengembangan mutu akademis. Dalam hal ini para dosen yang masih bergelar Magister, baik dosen tetap PNS maupun dosen Non-PNS diberi kesempatan yang sama untuk mengikuti Studi Lanjut pada tingkat Doktor, dengan ketentuan mereka harus telah mengabdi selama minimal 1 (satu) tahun. Mereka diperkenankan mengikuti studi lanjut dengan berkompetisi untuk memperoleh beasiswa di Kementerian Agama, dan Kementerian Keuangan. Hal ini sesuai dengan kutipan wawancara berikut:

IAIN Langsa memberi kesempatan yang sama bagi para dosen untuk mengikuti studi lanjut di universitas mana yang mereka inginkan. Kesempatan untuk mengikuti studi lanjut ini masih belum dibuat batasan-batasan kriteria dosen yang boleh dan belum boleh. Saat ini masih bebas, dosen tetap PNS dan Non PNS diberi hak yang sama untuk mengikuti Studi Lanjut dengan syarat mereka harus telah mengabdi selama 1 (satu) tahun dan mencari sumber-sumber pembiayaan masing-masing. Pada umumnya 
mereka ikut bersaing di Program Mora Scholarship pada Kemenag, dan LPDP di Kemenkeu (YS, 2019).

IAIN Langsa memberi kesempatan dan mendukung penuh keinginan para dosen yang masih bergelar Magister untuk melanjutkan studinya melalui pembiayaan beasiswa dari lembaga-lembaga yang menawarkan bantuan studi lanjut. Dalam pelaksanaannya, banyak para dosen yang mengikuti program tersebut, mereka bersaing di tingkat nasional untuk memperoleh bantuan studi lanjut dari para penyedia beasiswa tersebut, diantaranya Mora pada Kemenag, LPDP pada Kemenkeu, dan lain sebagainya. Masingmasing dosen tetap diberi kesempatan yang sama untuk melanjutkan studi, ke universitas yang mereka inginkan, namun harus sesuai kebutuhan kampus. Namun demikian, para dosen yang melanjutkan studinya harus telah terlebih dahulu mengabdi selama minimal satu tahun di IAIN Langsa.

Disamping itu, sebagai wujud kepedulian IAIN Langsa terhadap pengembangan mutu para dosen, institusi ini juga mengalokasikan anggaran studi lanjut dan memberikan dana bantuan studi tersebut setiap tahunnya.
IAIN Langsa mengalokasikan anggaran studi lanjut bagi dosen yang telah memenuhi syarat untuk bisa melanjutkan studi ke jenjang S3. Anggaran studi lanjut tersebut dianggarkan dan diberikan kepada lima orang dosen per tahunnya bagi mereka yang dianggap layak untuk menerimanya. Dana tersebut diberikan secara penuh kepada masing-masing dosen dan mereka dibebaskan dari tugasnya sebagai dosen atau status Tugas Belajar (SS, 2019).

Implementasi proses pengembangan mutu dosen dari sisi kapasitas akademisnya dianggap telah berjalan sesuai dengan harapan institusi. Keberhasilan tersebut tidak dapat dipungkiri bahwa sebagian besarnya atas adanya bantuan beasiswa yang mereka peroleh dari beberapa lembaga penyedia beasiswa tersebut. Disamping beasiswa yang mereka peroleh dari lembaga-lembaga tersebut, IAIN Langsa juga telah mengalokasikan anggaran beasiswa khusus untuk lima orang dosen setiap tahunnya.

Selain peningkatan kapasitas akademisnya, para dosen juga diberikan kesempatan untuk mengikuti berbagai kegiatan pelatihan, seminar, dan workshop 
baik di dalam maupun di luar kampus. Kegiatan tersebut misalnya berupa pelatihan pembuatan rencana pembelajaran semester (RPS), pelatihan penulisan karya ilmiah internasional, dan lain sebagainya. Namun demikian, kegiatan tersebut belum terjadwal dan masih kegiatan insidental tergantung kondisi anggaran yang ada. Sedangkan untuk kegiatan yang berada di luar kampus, institusi hanya mendukung pelayanan administrasi yang dibutuhkan oleh para dosen. Namun, terkadang para dosen dapat mengajukan permohonan bantuan dana untuk mengikuti kegiatan di luar kampus kepada masing-masing Fakultas, dan apabila fakultas tersebut memiliki dana, pihak fakultas dapat mengabulkannya.

\section{Pelaksanaan Pengembangan Mutu Dosen} di STAIN Gajah Putih Takengon

Pada bagian perencanaan telah dijelaskan bahwa pada umumnya usaha untuk pengembangan mutu dosen di lingkungan STAIN Gajah Putih Takengon belum direncanakan secara sistematis dari renstra, tetapi selalu dibahas pada rapatrapat awal dan akhir tahun. Demikian pula dengan pelaksanaannya, usaha untuk meningkatkan profesionalisme para dosen belum dilaksanakan secara intensif. Pelaksanaan pengembangan mutu dosen tergantung pada ketersediaan anggaran. Kegiatan yang dilakukan masih berupa pelatihan atau workshop yang berkaitan dengan pembelajaran, seperti pembuatan rencana pembelajaran semester (RPS) dan tentang proses pengusulan jabatan fungsional dosen, sebagaimana kutipan wawancara berikut ini:

Peningkatan mutu dosen di kampus kita ini masih belum dapat kita laksanakan secara maksimal, walaupun telah ditetapkan para renstra institusi. Kalau untuk CPNS memang setiap tahunnya dilaksanakan Diklat khusus berupa prajabatan, namun hal itu dilaksanakan oleh Balai Diklat Keagamaan Aceh, di Banda Aceh. Bagi dosen secara keseluruhan, kita belum dapat melakukan banyak hal terkait mutu dosen. Namun demikian, kita selalu berusaha untuk melakukan pengembangan mutu dosen itu secara maksimal yang kita bisa, misalnya baru-baru ini kita mengadakan pelatihan pembuatan RPS, dan juga pelatihan tentang kepangkatan dan jabatan fungsional bagi dosen. Terkait dengan peningkatan profesionalisme dosen dalam teknik dan strategi mengajar, pelatihan penelitian dan penulisan karya ilmiah di publikasi nasional dan internasional belum dapat kita 
lakukan, hal ini tentunya terkait dengan ketersediaan anggaran yang kita miliki (AS, 2019).

Dalam kutipan tersebut disampaikan bahwa usaha untuk meningkatkan mutu dosen telah dilaksanakan, namun demikian beliau menyadari belum banyak yang bisa mereka lakukan. Mereka melakukan usaha pengembangan mutu para dosen tergantung kepada ketersediaan anggaran yang ada, dan anggaran yang mereka miliki terkait hal ini masih sangat sedikit. Mereka belum melakukan usaha untuk meningkatkan kemampuan dosen dalam bidang penelitian dan publikasi ilmiah pada jurnal-jurnal nasional terakreditasi dan internasional bereputasi. PTAIN ini belum melakukan peningkatan profesionalitas dosen dalam hal strategi maupun teknik mengajar, belum melakukan kegiatan untuk meningkatkan pengetahuan para dosen sesuai dengan bidang keilmuannya.

Secara umum, STAIN Gajah Putih Takengon memotivasi para dosen untuk selalu meningkatkan profesionalitas mereka dalam berbagai hal yang mereka bisa lakukan. Namun demikian, institusi ini belum melakukan tindakan nyata dalam mengapresiasi prestasi yang diperoleh para dosen, misalnya memberikan reward atau penghargaan kepada para dosen yang berprestasi atau dosen yang memiliki kelengkapan pembelajaran yang baik, atau dosen yang memiliki karya ilmiah yang dipublikasi pada jurnal ilmial nasional terakreditasi atau internasional terbanyak, sebagaimana pada kutipan berikut:

Di kampus ini belum pernah dilakukan pemberian reward bagi para dosen yang dianggap punya prestasi yang baik, bagi dosen yang diketahui memiliki publikasi jurnal nasional dan internasional terbanyak. Reward tersebut tentunya akan menjadi motivasi yang baik bagi para dosen yang ada, dan menjadi suatu hal yang dapat menarik para dosen untuk melakukan hal-hal yang baik yang berkaitan dengan tugas dan fungsinya sebagai dosen, namun kita belum pernah melakukan itu, kemungkinan di tahun berikutnya akan kita lakukan. Hal ini juga telah diusulkan oleh beberapa staf agar tidak hanya memberikan punishment tetapi juga reward kepada para dosen sesuai dengan kriteria yang ada. Kita belum memberikan reward, tetapi punishment sudah, khususnya surat peringatan bagi mereka yang tidak melaksanakan tugas dengan baik atau disiplin yang baik (AS, 2019). 
Walaupun institusi ini belum melaksanakan usaha pengembangan mutu pada berbagai hal di atas, mereka telah melakukan usaha untuk meningkatkan mutu atau kapasitas akademik dosen. Para dosen diberikan kesempatan untuk melanjutkan studinya ke berbagai universitas yang mereka inginkan dengan biaya dari beberapa penyedia beasiswa. Pimpinan telah menjalin kerjasama dengan Bazis Kabupaten Bener Meriah, dan memohon bantuan untuk studi lanjut sebagian dosen. Beberapa dosen telah mengikuti studi lanjutnya dengan bantuan dana dari Bazis tersebut. Di samping itu, beberapa dosen juga telah mengikuti perkuliahan di tingkat Doktor dengan dana beasiswa Kementerian Agama Republik Indonesia, dan beberapa lainnya dengan bantuan dana dari lembaga lain.

Dari penjelasan di atas, pengembangan mutu dosen yang dilakukan PTAIN di Aceh dilaksanakan pada peningkatan kapasitas akademik para dosen melalui studi lanjut ke jenjang Doktor, peningkatan kemampuan profesionalisme dosen dalam melaksanakan tugas dan fungsinya melalui berbagai pelatihan, workshop dan seminar, misalnya pelatihan pembuatan RPS, pelatihan tentang kepangkatan dan jabatan fungsional dosen, dan sebagian tentang strategi dan teknik mengajar. Masing-masing PTAIN melakukan berbagai upaya dengan cara yang hampir sama, namun berbeda dalam intensitas pelaksanaannya. Semakin besar institusinya dan semakin besar anggaran yang dimilikinya, maka semakin banyak upaya yang bisa mereka lakukan untuk mutu dosennya. Strategi peningkatan kompetensi dan profesionalitas Dosen dilakukan melalui kegiatan peningkatan kemampuan Dosen di lingkungan internal (in-house training) maupun dilakukan di luar lewat kerjasama dengan Institusi lembaga pendidikan tinggi lainnya.

Bila dilihat dari segi pelaksanaannya maka secara umum upaya pembinaan tersebut dapat dibagi ke dalam dua jalur pembinaan, yaitu jalur pembinaan secara internal dan jalur pembinaan secara eksternal. Adapun jalur pembinaan secara internal merupakan upaya yang dilakukan sendiri, seperti pemanggilan dan pemberian peringatan, pengarahan dalam rapat kerja, dan pengajian rutin pada setiap bulannya.

Sedangkan jalur pembinaan secara eksternal merupakan upaya PTAIN dalam meningkatkan mutu Dosen melalui kerjasamanya dengan pihak lain (baca: pihak luar). Misalnya, kegiatan Pengembangan Kemampuan Dosen musyawarah Kelompok Kerja Dosen yang melibatkan pihak luar serta kegiatan studi 
banding ke PTAIN unggulan. Semua kegiatan dimaksud diarahkan bagi upaya peningkatan kompetensi dan profesionalitas Dosen PTAIN di Aceh.

Pengawasan, Monitoring dan Evaluasi

\section{Mutu Dosen PTAIN di Aceh}

Dari berbagai informasi yang diperoleh terkait pengawasan, monitoring, dan evaluasi terhadap mutu dosen, diketahui bahwa ketiga PTAIN di Aceh melakukan hal yang hampir sama, sehingga pada bagian ini peneliti tidak memisahkan pembahasan antara satu PTAIN dengan PTAIN yang lain. Pembahasan hasil temuan khusus terkait pengawasan, monitoring, dan evaluasi mutu dosen dilakukan sekaligus dengan menggabungkan dan menganalisis berbagai informasi dimaksud. Pengawasan, monitoring, dan evaluasi pengembangan mutu dosen di UIN Ar Raniry dilakukan secara langsung oleh para Ketua Program Studi dan Lembaga Penjaminan Mutu. Ketua Program Studi dan LPM adalah Pejabat yang memiliki peran dalam hal pengawasan, monitoring dan evaluasi tersebut. Dalam hal ini, dijelaskan sebagai berikut:

Tahap pengawasan, monitoring, dan evaluasi peningkatkan mutu tenaga Fungsional Dosen biasanya disampaikan pada rapat rutin setiap awal semester dan rapat akhir semester. Secara umum ada tiga aspek kinerja Dosen yang menjadi fokus penilaian, yaitu: kelengkapan perangkat pembelajaran, mutu pengajaran di ruangan dan sikap mental Dosen selama menjalankan tugas dan kewajibannya di ruangan. Yang terakhir ini, misalnya menyangkut kedisiplinan, tanggung jawab, dedikasi, kreatifitas, keaktifan, dan kerjasama serta interaksi sosial Dosen dengan sesama rekannya. Dalam pelaksanaan pengawasan, monitoring, dan evaluasi tersebut sebeumnya dilakukan oleh masingmasing Ketua Program Studi, dan pihak LPM (BM, 2019).

Berdasarkan hasil wawancara di atas dapat diketahui bahwa pengawasan, monitoring, dan evaluasi pengembangan mutu dosen disampaikan pada rapat rutin setiap awal semester dan rapat akhir semester. Peningkatan mutu dosen dapat diketahui melalui penilaian terhadap sejauhmana para dosen melakukan tugas dan tanggungjawabnya, sehingga pengembangan mutu itu tidak dapat dipisahkan dengan penilaian terhdap beberapa aspek terkait dengan pembelajaran. 
Beberapa aspek kinerja Dosen yang diawasi, dimonitoring dan dievaluasi, meliputi kelengkapan perangkat pembelajaran, pelaksanaan pengajaran dalam ruangan, dan sikap mental Dosen selama melaksanakan tugas dan kewajibannya di PTAIN. Pengawasan, monitoring, dan evaluasi dilakukan oleh Ketua Program Studi masing-masing dan LPM yang mempunyai tugas untuk itu.

Tahapan ini merupakan kegiatan penting untuk mengetahui kemajuan ataupun hasil yang dicapai terhadap pelaksanaan yang dilakukan lembaga dalam meningkatkan mutu pendidikan. Dalam konteks ini, evaluasi yang dilakukan idealnya merupakan evaluasi menyeluruh terkait dengan aspek-aspek kinerja Dosen, seperti Absen, beban kinerja Dosen serta evaluasi terhadap persiapan dan perangkat perkuliahan, evaluasi terhadap proses pembelajaran dan evaluasi terhadap kinerja mengajar dosen. Terkait evaluasi, dalam wawancara diperoleh keterangan sebagai berikut:

Pada prinsipnya kegiatan evaluasi dilakukan dengan cara mengamati, mengawasi kegiatan-kegiatan yang dilakukan Dosen selama melakukan proses mengajar di ruangan. Dalam pengamatan peneliti, konsep Evaluasi yang dikembangkan oleh PTAIN di Aceh lebih didasarkan pada keyakinan bahwa perbaikan merupakan suatu usaha kooperatif dari semua komponen yang terlibat dalam proses pembelajaran yang berlangsung.

Berdasarkan pengamatan peneliti, evaluasi yang dilakukan PTAIN di Aceh terhadap kinerja Dosen secara intensif dilakukan setiap awal semester dan akhir semester. Beberapa agenda yang biasa dibahas didalamnya meliputi: evaluasi ketercapaian program pembelajaran persemesternya melalui RPS dan presensi kehadiran Dosen dalam ruangan, hambatan/kendala yang dihadapi Dosen dalam pelaksanaan proses pembelajaran, permasalahan permasalahan dan hal-hal yang berkembang lainnya.

Rapat rutin yang dilakukan dalam setiap akhir semester merupakan bagian dari agenda setiap PTAIN Di Aceh yang wajib diikuti oleh semua unsur yang kedudukannya menjadi salah satu parameter penilaian komitmen Dosen terhadap aqad (kontrak mengajar) yang disepakatinya dengan pihak jurusan. Dalam kesempatan rapat tersebut, semua ketua Jurusan harus hadir dan antusias memberikan laporan dan masukannya.

Sebagaimana dipahami bahwa untuk mengetahui keberhasilan kinerja Dosen perlu dilakukan evaluasi atau penilaian 
kinerjanya dengan berpedoman pada parameter dan indikator yang ditetapkan,

Kutipan wawancara di atas yang diukur dengan tingkat keefektifan dan keefisiensian kerja seperti dilihat dari produktivitas mengajarnya, efektifitas penggunaan waktu, serta efisiensi penggunaan dana dan bahan bagi media pengajaran. Sedangkan evaluasi kinerja melalui penilaian perilaku Dosen dilakukan dengan cara membandingkan dan mengukur perilaku seseorang dalam menjalankan perintah atau tugas yang diberikan. Hal terkait disebutkan pula bahwa:

Ada beberapa bentuk pelaksanaan yang diterapkan kepada para Dosen, di antaranya yaitu: pengawasan terhadap proses pembelajaran, kehadiran para Dosen, media pembelajaran, bahan ajar dan persiapan sebelum mengajar dalam ruangan. Selanjutnya, evaluasi dilakukan melalui penyebaran angket baik kepada dosen maupun mahasiswa. Pada setiap akhir proses pembelajaran semester, pihak LPM melakukan evaluasi untuk mengetahui kualitas proses pembelajaran selama satu semester. Hasil evaluasi ini akan menjadi bahan dalam pengambilan kebijakan untuk semester berikutnya (SS, 2019) menggarisbawahi bahwa PTAIN di Aceh lebih fokus dalam melakukan pengawasan terhadap proses pembelajaran. Artinya, tindakan absensi dosen dan mahasiswa, secara rutin dilaksanakan. Hal ini penting dilakukan karena untuk menghasilkan output pendidikan yang baik diperlukan pengawasan terhadap proses pendidikannya.

Secara umum dapat dikemukakan adanya tiga bentuk pelaksanaan yang dilakukan PTAIN di Aceh dalam upaya meningkatkan mutu pendidikan, yaitu: pengembangan mutu dosen terhadap perangkat administrasi Dosen terutama sekali perangkat pembelajarannya, pengembangan mutu dosen terhadap pelaksanaan proses pembelajaran melalui kunjungan ruangan dan Absen Dosen, dan pengembangan mutu dosen terhadap kinerja Dosen. Hal ini sekaligus menegaskan bahwa apa yang dikemukakan pihak institusi kepada peneliti adalah benar adanya.

Terkait dengan pelaksanaan pengawasan kinerja Dosen, berdasarkan wawancara dengan Pimpinan Pusat Penjaminan Mutu, dikemukakan sebagai berikut:

Pengawasan terhadap persiapan mengajar Dosen, seperti RPS biasanya kami lakukan setiap akhir semester. 
Pengawasan terhadap catatan absensi dilakukan pada setiap minggunya. Sedangkan pengawasan terhadap perangkat pembelajaran dilakukan per semester. Maka, tidak jarang revisi terhadap perangkat pembelajaran tersebut kami terapkan kepada DosenDosen. Dengan harapan berbagai kekurangan yang ditemukan di dalamnya segera dapat diperbaiki. Adapun momen yang biasa kami gunakan dalam menyampaikan penilaian kinerja Dosen adalah melalui rapat rutin mingguan dan rapat akhir semester (AS, 2019)

Kutipan wawancara di atas menunjukkan bahwa intensitas pengawasan terhadap perangkat mutu dosen tergolong cukup ketat. Dalam hal ini pengawasan terhadap persiapan mengajar Dosen silabus atau RPS dilakukan setiap minggunya atau semesternya. Selanjutnya, pengawasan, monitoring, dan evaluasi terhadap pengembangan mutu dosen diukur melalui laporan beban kinerja dosen pada setiap akhir semester. Hal ini dijelaskan oleh beberapa pihak dari ketiga institusi. Mereka mengatakan bahwa mutu dosen dapat pula dilihat dari Rencana Beban Kerja Dosen (RBKD) Laporan Beban Kinerja Dosen (LBKD) yang harus dibuat oleh semua dosen. RBKD dan LBKD merupakan kewajiban bagi semua dosen untuk membuat dan menyampaikannya kepada pimpinan fakultas masing-masing yang disampaikan kepada pihak LPM/P2M untuk diassessment oleh para asesor yang ditetapkan oleh Rektor. RBKD dan LBKD tersebut dibuat setiap semester untuk mengukur pelaksanaan tugas yang dilakukan selama satu semester. Rencana dan Laporan ini juga berfungsi sebagai dilakukan atau tidaknya tunjangan sertifikasi bagi dosen yang telah memiliki sertifikat pendidik (MZ, 2019; SS, 2019; AS, 2019).

Demikian halnya karakteristik pengawasan dalam perspektif Islam, bahwa pelaksanaan pengawasan tidak saja terhadap aspek material juga spiritual. Bahkan, pelaksana monitoring bukan hanya manajer, tapi juga Allah SWT. dengan menggunakan metode yang manusiawi yang menjunjung tinggi martabat manusia. Pengawasan dalam Islam dilaksanakan untuk memperbaiki yang salah, menilai dan membenarkan yang hak. Pengawasan di dalam Islam pada dasarnya terbagi kepada dua hal, yaitu: (1) pengawasan yang berasal dari individu, yang bersumber dari aqidah dan keimanan kepada Allah SWT dan (2) pengawasan dari Allah SWT. 
Dalam pengawasan, monitoring, dan evaluasi, ada 2 aspek yang dilihat, yaitu: pertama, aspek perangkat pembelajaran dengan indikator atau sub indikator meliputi: program tahunan, program semester, RPS, kalender pendidikan, jadwal tatap muka, daftar nilai, ujian tengah semester, ujian akhir semester, agenda harian, dan absensi mahasiswa.

Kedua, aspek proses pembelajaran dengan indikator/sub indikator meliputi: penerapan 4 persyaratan penguasaan ruangan, yaitu: perencanaan, pelaksanaan, penilaian dan tindak lanjut; penerapan metode dan pendekatan tatap muka, kegiatan terstruktur dan kegiatan mandiri tidak terstruktur; penerapan media pembelajaran dalam kegiatan terstruktur dan kegiatan mandiri tidak terstruktur.

\section{E. KESIMPULAN}

Pelaksaaan pengembangan mutu dosen pada umumnya mengacu pada renstra yang ada, dan berbagai rencana yang telah dibahas dan diputuskan pada rapat. Bentuk pelaksanaan pengembangan mutu dosen tersebut di antaranya untuk meningkatkan kemampuan akademik dosen melalui studi lanjut program Doktor, dan meningkatkan kompetensi dan profesionalitas dosen melalui berbagai pelatihan, seminar dan workshop di dalam maupun di luar institusi masing-masing.

Pengawasan, monitoring, dan evaluasi terhadap pengembangan mutu dosen PTAIN di Aceh dilakukan secara langsung oleh Ketua Program Studi dan Lembaga Penjaminan Mutu sebagai bagian yang bertugas untuk mengawasi, memonitor, dan mengevaluasi kemapuan dosen dalam melaksanakan tugas dan tanggungjawabnya. Pengawasan, monitoring, dan evaluasi tersebut dilakukan dengan pengecekan berbagai kelengkapan perangkat pembelajaran, melakukan kunjungan ke ruangan, melihat kedisiplinan para dosen melalui presensi kehadiran dosen. Penyimpangan yang ditemukan ditindaklanjuti dengan pemberian punishment dan reward. Hasil evaluasi menjadi bahan pertimbangan guna melakukan pembinaan lebih lanjut kepada para Dosen. Adapun bentuk-bentuk pembinaan yang dilakukan terhadap para Dosen meliputi upaya pemanggilan dan pemberian peringatan, pemberian pelatihan bagi peningkatan kompetensi dan profesionalitas Dosen, musyawarah melalui rapat kerja, pengajian, dan studi banding ke PTAIN unggulan.

\section{DAFTAR PUSTAKA}

Abdullah, M. A. (2017). Islamic Studies in Higher Education in Indonesia: 
Challenges, Impact and Prospects for the World Community. Al-Jami'ah: Journal of Islamic Studies, 55(2), 391426.

Acs, Z. J., Szerb, L., \& Autio, E. (2015). Global Entrepreneurship and Development Index 2014. https://doi.org/10.1007/978-3-31914932-5

Amtu, O. (2011). Manajemen Pendidikan di Era Otonomi Daerah: Konsep, Strategi, dan Implementasi. Alfabeta Bandung.

Arwildayanto, D. M. P., \& Pd, M. (2012). Manajemen Sumber Daya Manusia Perguruan Tinggi Pendekatan Budaya Kerja Dosen Profesional. Gorontalo: Ideas Publishing.

Badan Pusat Statistik (BPS). (2020). Indeks Pembangunan Manusia (IPM) Indonesia pada tahun 2019 mencapai 71,92. Retrieved from Indeks Pembangunan Manusia (IPM) website: https://www.bps.go.id/pressrelease/20 20/02/17/1670/indeks-pembangunanmanusia--ipm--indonesia-pada-tahun2019-mencapai-71-92.html

Bashori, B., Prasetyo, M. A. M., \& Susanto, E. (2020). Change Management Transformation in Islamic Education of Indonesia. Social Work and Education, 7(1), 72-85.

Dhaniarti, I., Putra, B., Setiawan, M., \& Sukoco, A. (2016). Entrepreneurship Education in Islamic Community: Its Application in Human Resource Planning and Development Course. Researchgate.Net.

Fadjar, M. (2001). Platform Reformasi Pendidikan dan Pengembangan SDM. Jakarta: Logos Wacana Ilmu.

Moleong, L. J. (2011). Metodologi Penelitian Kualitatif: Edisi Revisi. Bandung: Remaja Rosda Karya.

Mukhtar, H., \& Prasetyo, M. A. M. (2020). Pesantren Efektif Model Teori Integratif KepemimpinanKomunikasi-Konflik Organisasi.
Deepublish.

Nasr, S. H., \& Leaman, O. (2013). History of Islamic Philosophy (Vol. 1). Routledge.

Rosita, S., \& Musnaini, D. M. F. (2020). Commitment, Satisfaction and Motivation in Improving Organizational Citizenship Behavior and Its Impact on Lecturer Performance in Higher Education.

Sahpitri, N., Prasetyo, M. A. M., \& Zulkhairi. (2019). Strategi Peningkatan Layanan Akademik Berbasis Kinerja Karyawan di Fakultas Tarbiyah dan Ilmu Keguruan IAIN Lhokseumawe. Idarah (Jurnal Pendidikan Dan Kependidikan), 3(2), 84-101.

Sallis, E. (2012). Total Quality Management in Education, Fourth Edition. London: Kogan Page.

Wajdi, M. B. N. (2016). Metamorfosa Perguruan Tinggi Agama Islam. ATTahdzib: Jurnal Studi Islam Dan Muamalah, 4(1), 92-109.

Yorke, M. (2000). Developing a Quality Culture in Higher Educaiton. Tertiary Education and Management, 6(1), 1936.

Yusuf Qordhowi, Pendidikan Islam dan Madrasah Hasan Al-Banna, , Sejarah UIN Ar Raniry, dikutip dari http://uin.arraniry.ac.id/index.php/id/pages/sejarah, diakses pada 25 Oktober 2019. , Sejarah IAIN Langsa, dikutip

dari

https://www.iainlangsa.ac.id/pages/visidan-misi, diakses pada 25 Oktober 2019. , Sejarah Singkat STAIN Gajah Putih Takengon, Aceh. Dikutip dari http://stain-gp.ac.id/pages/Sejarah, diakses pada 25 Oktober 2019.

Zarkasyi, H. F. (2012). Liberalism, Liberalization and Their Impacts of Muslim Education (Special Case of Indonesian Intellectuals). TSAQAFAH, 8(1), 183-210. 
Zein, M., Ali, A., \& Zin, M. (2018). Integrative Concept And Approaches in National Education and Islamic Education. AL-MUQADDIMAH: Journal of Postgraduate Studies In
Islamic History and Civilization, 6(2), 15-30. 
